Mevlut AYDOGMUS*

Necmettin Erbakan University

Konya, Turkey

Cihad SENTURK

Karamanoglu Mehmet Bey University

Karaman, Turkey
Original scientific paper

UDC: 378.1 .14

DOI: $10.17810 / 2015.87$

\title{
THE EFFECTS OF LEARNING STATIONS TECHNIQUE ON ACADEMIC ACHIEVEMENT: A META-ANALYTIC STUDY
}

\begin{abstract}
In this study, the effectiveness of the learning stations technique and experimental investigations are tested by comparing this method to the traditional teaching method. A meta-analytical impact analysis method was used to calculate the effect size of the learning stations technique on academic achievement. Studies conducted in Turkey between the years 2000 and 2018 were included in this study. Eight selection criteria were identified and 13 studies that met the meta-analyze criteria were selected for the meta-analysis. The data was processed using the Comprehensive Meta Analysis (CMA) program. Results showed that the effect size of the learning stations technique on academic achievement was .84. According to Cohen et al. (2000), this is a large effect size. The impact levels of the teaching practices are organized according to the learning stations technique according to teaching stage, application duration, research type, and course type. A significant difference was found between the effect size values calculated according to course type. The results showed that the learning stations technique is more effective than the traditional teaching method.
\end{abstract}

Keywords: Academic achievement, learning stations technique, meta analysis, effect size.

\section{Introduction}

Change is an inevitable reality of life. Countries, cultures, ways of thinking and production, relations and nature are constantly changing. Any person is constantly changing throughout his or her lifetime (Erdogan, 2012). These personal changes produce a compound effect of social, economic and technological developments, and a transformation based on knowledge ensues (Gurbuz, 2011). It is not possible to think about education systems and learning approaches independently of developments, changes and transformations in other fields (Ozden, 2005). The developments that have emerged in the dizzying twenty-first century, of course, also affect the educational system and the way of thinking towards learning, which in turn leads to the need to reconsider the aims, content and learning-teaching methods of education (Council of Europe, 2015). This is why in Turkey constructivist educational programs were prepared in line with the constructivist approach in 2005, and the teaching process

\footnotetext{
*maydogmus@erbakan.edu.tr
} 
constructivist learning and teaching conception was adopted. Educational programs were updated in 2012 with $4+4+4$ education reforms and in 2017 they were revised in the direction of developments in the world by referring to public opinions and revised in the direction of progressive philosophy and the constructivist approach. In this context, the constructivist approach and collaborative learning model are included in curriculums (primary and secondary education) and learning stations techniques are included in this model.

There are many techniques developed in the literature in accordance with the cooperative learning model. Student teams, success parts, team-based game tournaments, unified readings and compositions based on cooperation, team-supported individualization, mutual interrogation, unification, learning centers, and station techniques are some of those (Senemoglu, 2007: 501). The learning stations became a well-known model in the 1960's and 1970's, based on Montessori at the beginning of the 1900's, then shaped by Dewey's educational philosophy, and then influenced by Piaget and Vygotsky's constructivist views. In our contemporary education system, the learning stations technique is used as a teaching tool that addresses individual differences and is supported by the multiple intelligences theory (Demir, 2008). The learning stations technique aims to take active learning opportunities for students and to move education beyond the traditional classroom through multidimensional applications (Ocak, 2008: 250).

The learning stations technique is a form of course processing in which students perform a series of learning activities in specific areas created in the learning-teaching process (within the classroom or outside the classroom) by working individually or in groups with the help of specific guidelines created by the teacher or student teacher in order to learn or review a topic (Benek \& Kocakaya, 2012: 10). It is a student-centered technique in which the class is divided into groups, teaching the groups to contribute to the work done by previous groups and to complete half-finished projects (Gozutok, 2007). The stations are small learning and activity areas where students can work on different themes at the same time and switch between stations (Tomlinson, 1999, 2001). In the stations, students work as a group under their teacher's guidance, are responsible for their own learning experiences, encounter research and exploration opportunities, have rich learning experiences, do different activities and use different materials to learn, and experience reinforcement of what they have learned. Stations are areas where students are responsible for their own learning while using a variety of materials (Benek, 2012; Benek \& Kocakaya, 2012; Pohtola, 2015). The learning stations technique is a modern technique that enables students to work independently, use plenty of tools and materials, not experience passive listening monotony, be actively incorporated into the learning process, and experience greater retention of the information learned with the aid of audiovisual tools (Demirors, 2007).

Prior to the application of the station technique, students are divided into heterogeneous groups, taking into account the type of interest, dominant intelligence, learning profile, and classroom. Created student groups are actively involved in learning activities at pre-prepared stations according to the feature of the subject (Ocak, 2010, 2015). In this way, students enjoy active participation in these groups and find opportunities to collaborate, socialize and develop communication skills. Stations also help to socialize asynchronous or asocial students (Yuksel, 2017).

When the research on the subject was examined, it was seen that the learning stations technique has important contributions to academic achievement, retention rates, and 
attitudes (Albayrak, 2016; Aslan, 2017; Benek, 2012; Cakmak, 2018; Demir, 2008; Erdagi, 2014; Yuksel, 2017). In this study, the findings of the research about the effect of the station technique on academic achievement were combined with the meta-analysis method. This study was designed to evaluate the effectiveness of learning stations, compared to other methods.

\section{Methodology}

This research was conducted using the meta-analysis method. Hedges and Olkin (1985) define meta-analysis study as quantitative methods that are used prominently to express or combine the results of different researches. As a research synthesis, meta-analysis is an increasing dayto-day method with the function of meaningfully combining and interpreting the results from a large number of research studies. One of the most powerful aspects of this method is that it provides guidance to policy makers in light of scientific evidence and has the potential to explain inconsistent results in the literature (Ustun \& Eryilmaz, 2014).

The method of meta-analysis is widely used in the field of education (Igel, 2010). Meta-analysis is the method of combining the results of multiple independent studies in a given subject and making statistical analysis of the research findings obtained. The specific aspect of metaanalysis is that it uses rather quantitative methods instead of trusting intuitive judgment alone. In this respect, the method of meta-analysis distinguishes the literature from the classical approach (Akgoz, Ercan \& Kan, 2004).

\subsection{Data Collection}

The sample of this study constitutes research conducted in the field of learning stations technique. Key words to be used in the literature search were determined first to gather the data. The key words determined are given in Table 1.

Table1. Key words used to reach the data

\begin{tabular}{l}
\hline Turkish Key Words \\
\hline İstasyon Tekniği (Station Technique) \\
\hline Öğrenme İstasyonları (Learning Stations) \\
\hline
\end{tabular}

6 electronic databases (Eric, EBSCO, Dergipark, Science Direct, Tukish Higher Education Institution National Thesis Center, Google Academic searched for the key words. In this way, a total of 29 researches including 11 graduate thesis and 18 articles have been reached.

\subsection{Criteria for Inclusion in the Meta-analysis}

The selection criteria for the studies used in this meta-analysis study are as follows:

1. The studies carried out between the years of 2000 and 2018.

2. The study is unpublished thesis or published in a scientific, peer-reviewed journal.

3. The studies which has experimental and control groups of research.

4. The studies where learning stations used in both experiment and control groups.

5. The studies which have sample sizes, standard deviation and arithmetic averages.

6. The Learning Station Technique is clearly described and implemented.

7. The studies which executed in primary, secondary and university level. 
The reached studies examined according to the above criteria and 13 studies, including 9 master theses and 4 articles, were included in the meta-analysis. When there was more than one measurement in a study, each measurement was included to the meta-analysis. A total of 16 measurements were included in the meta-analysis study.

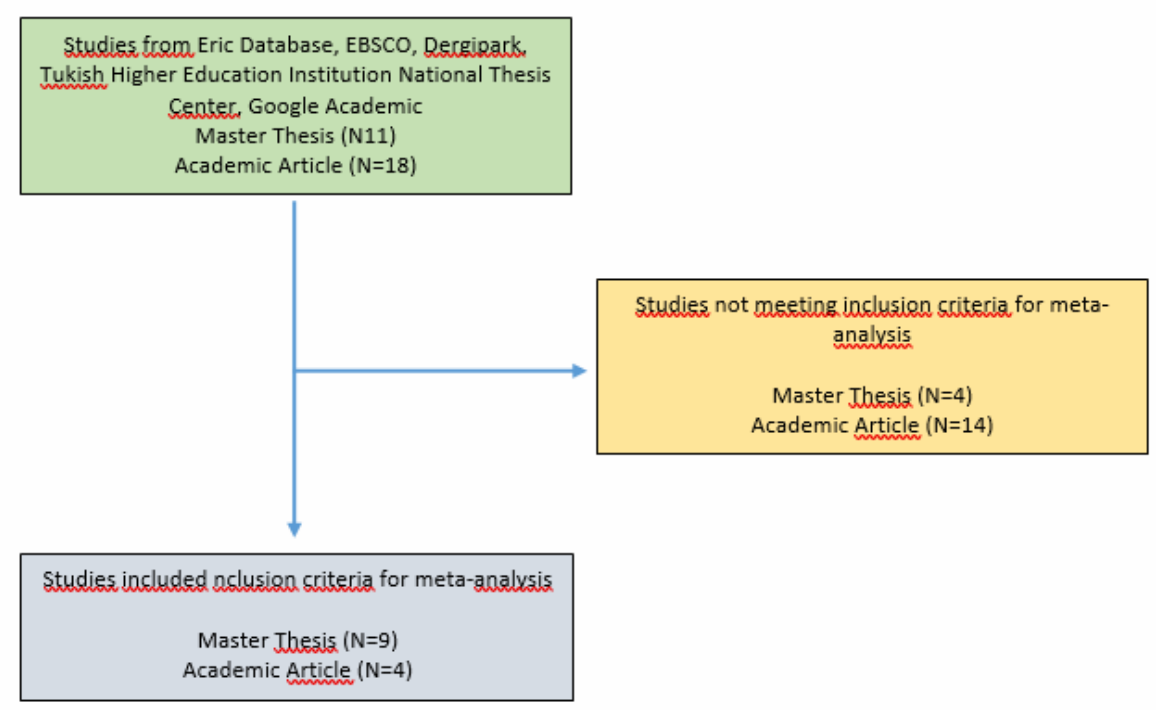

Figure 1. Studies regarding criteria for inclusion in the meta-analysis

\subsection{Data Analysis}

In this study, values related to effect size, variance and heterogeneity of independent studies included in the study were calculated by using Comprehensive Meta-Analysis (CMA) 2.0. The experimental group used the learning stations technique and the control group used the traditional teaching activities. In this respect, the calculated positive effect size values will indicate that the learning stations technique is more effective than traditional teaching activities on the achievement. Confidence level was selected as $95 \%$ in studies involving metaanalysis. In this respect, the confidence level of the statistical analyses in the meta-analysis study was determined as $95 \%$. Calculated effect size values are interpreted as follows: a small effect size is between .20 and .19 , a moderate effect size is between .50 and .79 , and a large effect size is .80 and over (Cohen, 1998). Within the scope of the research, a coding form was developed to provide identification and content information of the studies that will be included in the meta-analysis. The coding form included codes for the authors of the study, the type of research, the year of the study, the duration of the study, the level of education and discipline, the mean, standard deviation, and the number of samples for the experimental and control groups. 
In the case of studies where more than one measurement is made, each measurement is included independently in the meta-analysis. The coding form used in the research was written separately by two people. The percentage of compliance is calculated to determine the level of reliability due to coding between encoders. The consistency was found to be $95 \%$. This value shows that there is a high level of consistency between the coders and that coding reliability is provided.

\subsubsection{Descriptive Statistics}

Descriptive information about the studies included in the meta-analysis is given in Table 2. The type of research, discipline, duration, meta-analysis is included as a step moderator variable. In Table 2. Frequency and Percentage of the Studies According to Type, Level, Course, Period and Year Variables.

Table 2. Frequency and percentage of the studies

\begin{tabular}{|c|c|c|c|}
\hline & Moderator & Moderator Frequency (f) & Percentage (\%) \\
\hline$\stackrel{\Perp}{\beth}$ & $\begin{array}{c}\text { Article } \\
\text { Master's thesis }\end{array}$ & $\begin{array}{l}4 \\
9\end{array}$ & $\begin{array}{l}51,3 \\
30,8\end{array}$ \\
\hline $\bar{\Xi}$ & $\begin{array}{l}\text { Primary } \\
\text { Secondary } \\
\text { University }\end{array}$ & $\begin{array}{c}11 \\
1 \\
1\end{array}$ & $\begin{array}{c}84,6 \\
7,7 \\
7,7\end{array}$ \\
\hline 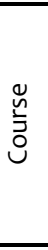 & $\begin{array}{c}\text { Science and Technology } \\
\text { Physics } \\
\text { General Chemistry Knowledge of } \\
\text { life } \\
\text { Math } \\
\text { Social studies } \\
\text { Turkish } \\
\end{array}$ & $\begin{array}{l}6 \\
1 \\
1 \\
1 \\
1 \\
1 \\
2\end{array}$ & $\begin{array}{l}46,2 \\
7,7 \\
7,7 \\
7,7 \\
7,7 \\
7,7 \\
15,4 \\
\end{array}$ \\
\hline$\frac{\overline{0}}{2}$ & $\begin{array}{c}2 \text { weeks } \\
3-4 \text { Weeks } \\
5 \text { Weeks and Over }\end{array}$ & $\begin{array}{l}4 \\
5 \\
4 \\
\end{array}$ & $\begin{array}{l}30,8 \\
38,5 \\
30,8\end{array}$ \\
\hline 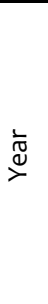 & $\begin{array}{l}2008 \\
2009 \\
2010 \\
2011 \\
2012 \\
2013 \\
2014 \\
2016 \\
2017\end{array}$ & $\begin{array}{l}1 \\
1 \\
2 \\
1 \\
1 \\
1 \\
2 \\
2 \\
2\end{array}$ & $\begin{array}{c}7,7 \\
7,7 \\
15,4 \\
7,7 \\
7,7 \\
7,7 \\
15,4 \\
15,4 \\
15,4\end{array}$ \\
\hline
\end{tabular}

When the table is examined, it is found that $51.3 \%$ of the studies included in the meta-analysis are articles and $30.8 \%$ are Master's theses. A large proportion of studies using learning stations technique were conducted in primary education (84.6\%). It is understood that this technique is mostly used in science and technology classes (46.2\%). The learning stations technique was applied for 2 weeks in $30.8 \%$ of the studies, for $3-4$ weeks in $38.5 \%$, and for 5 weeks or more in $30.8 \%$. A large proportion of the studies involved in meta-analysis were conducted between 2014 and 2017. 


\section{Results}

The higher likelihood of acceptance of studies which are statistically significant and consistent with the literature by scientific journals leads to a bias in favour of studies that are consistent with the literature and have statistically significant results. Meta-analysis studies using the results of field studies are directly influenced by bias (Rothstein, Sutton \& Borenstein, 2005). In this respect, it is very important to determine whether there is bias before the metaanalysis, and if so, to what extent the bias is. A high level of publication bias can manipulate the calculated mean effect size to be higher or lower than necessary (Borenstein, Hedges, Higgins \& Rothstein, 2009). In determining the publication bias, the Funnel Scatter Graph, Crop and Fill, and Fail Safe N methods of Rosenthal and Orwin were used (Ustun \& Eryilmaz, 2014).

\subsection{Funnel Scatter Graph and Crop and Fill Method}

The funnel graph has two axes, $X$ and $Y$. The first of these $(X)$ axis show the effect size values and the other $(Y)$ gives standard error values. While values belonging to studies with small sampling in the graph are scattered in a large area in the lower layer, values in the large sample are scattered in the upper layer in a smaller area. When the funnel graph obtained in this study is examined, it is seen that the effect sizes of the studies are around the main effect size and have a relatively symmetrical distribution (Figure 1). When the Crop and Fill method was used, it was observed that a 2-dummy study was added to the funnel graph to eliminate the bias of the publication. In this way, the effect size value of the works falls to 0.852 or 0.752 . According to this method, it is understood that in the case of finding the bias of publication, the studies which cannot be obtained will change the calculated effect value for achievement in a very small percent.

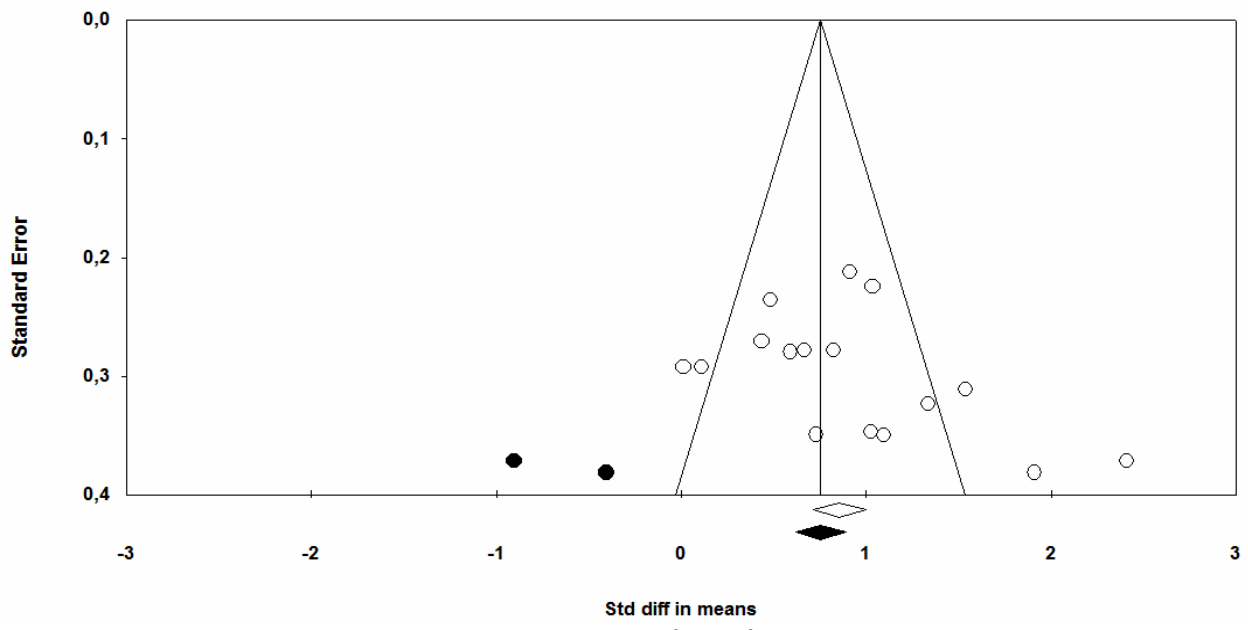

Figure 2. Funnel Graph 


\subsection{Safe N Method}

Using this method, it is possible to calculate the number of works should be added to the meta-analysis in order to reset the effect size value obtained from the meta-analysis (Rothstein, Sutton, \& Borenstein, 2005). If the Secure $\mathrm{N}$ value obtained by this method is considerably higher than the number of studies included in the study, it is assumed that the effect value obtained by meta-analysis is highly resistant to publication bias. In the method proposed by Orwin, it is possible to calculate how many new works are needed in order to move the effect value obtained by meta-analysis to a different level (Rothstein, Sutton \& Borenstein, 2005). In this study, Rosenthal's Fail-Safe N value was calculated as 613. According to Orwin's Fail Safe N Method, 119 new studies with a zero effect are required to reduce the computed overall effect size to a value of 0.1 selected as "nonsignificant" (Table 3). The number of new studies obtained from both methods was significantly higher than the number of studies included in the study, indicating that this study was highly resistant to bias.

Table 3. Rosenthal and Orwin's Safe N method results

\begin{tabular}{lcll}
\hline \multicolumn{1}{c}{ Rosenthal Safe N Method } & \multicolumn{2}{c}{ Orwin's Safe N Method } \\
\hline Z-value for observed studies & 12,29 & Hedge's g for the observed studies & 0,85 \\
p-value for observed studies & 0,00 & Criterion for “Nonsignificant” Hedge g & 0,1 \\
Alpha & 0,05 & Average Hedge g for lost studies & 0,00 \\
Direction & 2 & N Value & 119 \\
Z value for Alpha & 1,96 & & \\
The number of observed studies & 16 & & \\
N value & 613 & \\
\hline
\end{tabular}

\subsection{Unified Findings}

The mean effect size and confidence intervals according to the fixed and random effects model of the studies in the meta-analysis are given in Table 4. The value of the learning stations technique's effectiveness was calculated to be .84 according to the fixed effects model and .90 according to the random effects model. On the other hand, the $\mathrm{Q}$ value calculated by the homogeneity test shows that distributions of success data have a heterogeneous structure $(\mathrm{Q}=54.69 ; \mathrm{p}<0.001)$. In accordance with this result, it has been decided to carry out analyses according to the model of random effects and remove the illusions arising from the heterogeneity of the sample (Yildiz, 2002). Using the random effects model, the effectiveness of the instruction based on the learning stations technique and the traditional teaching on success were compared. According to the average effect value obtained, the average effect size of 16 studies based on the learning stations technique success was calculated as 0.84 . This calculated value shows a large effect according to Cohen's (1998) classification. 
Table 4. Meta-analyzes effect model values of included studies, homogeneous distribution value, average effect size, and confidence intervals

\begin{tabular}{|c|c|c|c|c|c|c|c|c|c|c|c|}
\hline \multirow[b]{2}{*}{ Model } & \multicolumn{6}{|c|}{$\begin{array}{l}\text { Effect size and } 95 \% \text { confidence } \\
\text { interval }\end{array}$} & \multicolumn{2}{|c|}{$\begin{array}{c}\text { Absence } \\
\text { Hypothesis }\end{array}$} & \multicolumn{3}{|c|}{ Heterogeneity } \\
\hline & 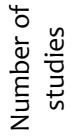 & 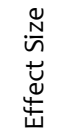 & 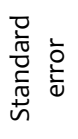 & 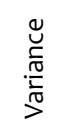 & 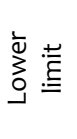 & 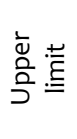 & $\frac{\stackrel{0}{J}}{\frac{\pi}{\pi}}$ & உ & $\begin{array}{l}\frac{0}{\partial} \\
\frac{\pi}{0} \\
0\end{array}$ & $\underset{\frac{\pi}{t}}{\widetilde{c}}$ & $\simeq$ \\
\hline Fixed Effects & 16 & 0,84 & 0,07 & 0,00 & 0,70 & 0,98 & 11,92 & 0,00 & $\begin{array}{l}54,6 \\
9\end{array}$ & $\begin{array}{l}15,0 \\
0\end{array}$ & $\begin{array}{c}72,5 \\
7\end{array}$ \\
\hline $\begin{array}{l}\text { Random } \\
\text { Effects }\end{array}$ & 16 & 0,90 & 0,14 & 0,02 & 0,63 & 1,17 & 6,56 & 0,00 & & & \\
\hline
\end{tabular}

The $I^{2}$ values obtained from the meta-analysis give information on the homogeneity of the calculated effect values (Borenstein et al., 2009). The fact that the $I^{2}$ values obtained from the meta-analysis were higher than $70 \%$ showed that the effect values on the success of the studies included in the study had a heterogeneous distribution (Table 4). In order to identify factors that cause heterogeneous distribution of studies included to the meta-analysis moderators variable like type, duration of application, the stage of education and the discipline area in which it was implemented were created. Moderators are independent variables that are thought to influence the results obtained in meta-analysis studies (Kis \& Konan, 2014). Subgroup analyzes were conducted to test the moderator variables identified in the study.

Meta Analysis

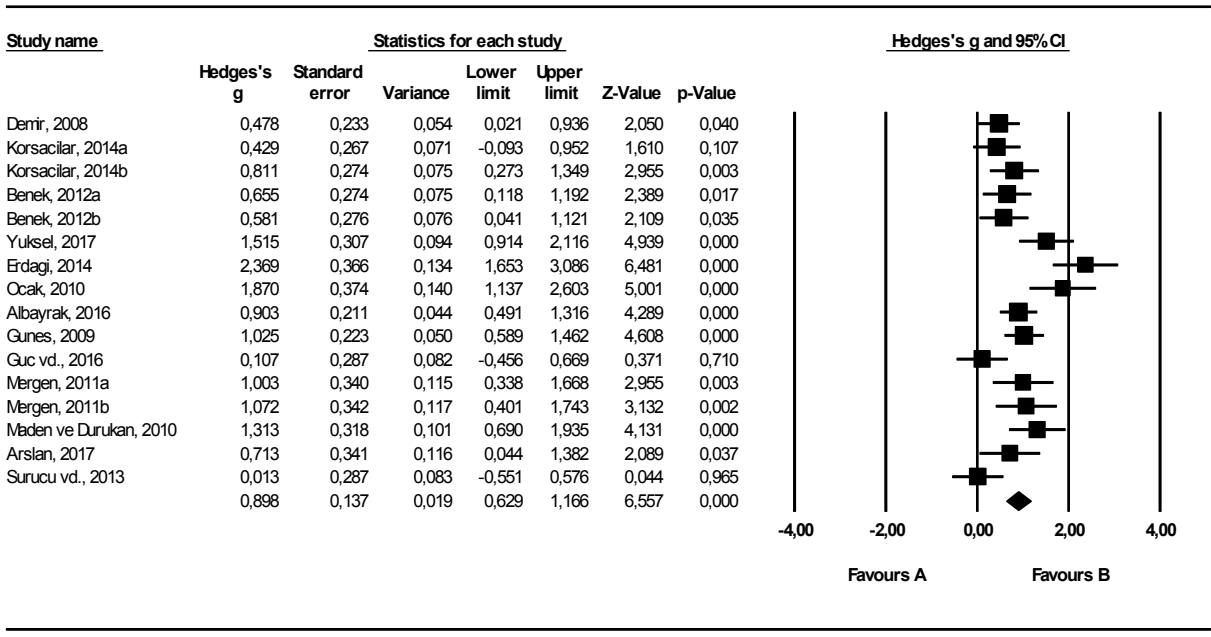




\subsection{Subgroup Analysis Results}

In order to investigate whether the effect sizes of the teaching practices organized according to the learning stations technique differed according to the level of education, the studies included in the study were divided by primary school, secondary school, and university. According to the results of the analysis, the average effect size values calculated for primary education, secondary education, and university levels were 1.012, 0.615 , and 0.013 respectively. According to the homogeneity test result, there was a significant difference between the effect size values calculated by education level $\left(Q_{B}=10.083 ; p=0.006\right)$. The average effect on the achievement of the studies done at the primary education level was highest.

It was found that the learning stations technique applications in this meta-analysis were applied for different durations. In order to determine whether this impacted the success of learning stations, the studies were divided into 3 groups as follows: 2 weeks and less, 3-4 weeks, and 5 weeks and more. According to the results of the analysis, the average effect size values calculated according to the periods of 2 weeks and less, 3-4 weeks, and 5 weeks and more of the studies were $0.804,1.192$, and 0.703 respectively. According to the homogeneity test result, there was no significant difference between the effect size values calculated according to the application period of the studies performed $\left(Q_{B}=2.242 ; p=0.326\right)$.

Table 5. According to moderator variables examining the effects on the success of teaching practices based on learning stations technique

\begin{tabular}{lcccccc}
\hline Moderator & $\mathrm{k}$ & $\mathrm{d}$ & $\mathrm{SE}$ & $\% 95 \mathrm{Cl}$ & Qbetween & $\mathrm{p}$ \\
\hline Level of Educaion & 16 & & & & 10,083 & 0,006 \\
$\quad$ Primary & 13 & 1,012 & 0,151 & 0,$716 ; 1,308$ & & \\
Secondary & 2 & 0,615 & 0,191 & 0,$240 ; 0,989$ & & \\
$\quad$ University & 1 & 0,013 & 0,287 & $-0,551-0,576$ & & \\
\hline Duration of instruction & 16 & & & & 2,242 & 0,326 \\
2 week or less & 5 & 0,804 & 0,264 & 0,$287 ; 1,322$ & & \\
3-4 weeks & 6 & 1,192 & 0,306 & 0,$593 ; 1,791$ & & \\
5 weeks and over & 5 & 0,703 & 0,120 & 0,$468 ; 0,937$ & & \\
\hline Type of the study & 16 & & & & 0,074 & 0,786 \\
Article & 4 & 0,804 & 0,439 & $-0,057 ; 1,664$ & & \\
Master's thesis & 12 & 0,928 & 0,133 & 0,$668 ; 1,188$ & & \\
\hline Implementation Discipline & 16 & & & & 20,057 & 0,003 \\
Science and technology & 7 & 1,224 & 0,217 & 0,$799 ; 1,649$ & & \\
Physics & 2 & 0,615 & 0,191 & 0,$240 ; 0,989$ & & \\
General Chemistry & 1 & 0,013 & 0,287 & $-0,551 ; 0,576$ & & \\
Knowledge of Life & 1 & 0,478 & 0,233 & 0,$021 ; 0,936$ & & \\
Math & 1 & 0,107 & 0,287 & $-0,456 ; 0,669$ & & \\
Social studies & 2 & 1,037 & 0,241 & 0,$565 ; 1,510$ & & \\
Turkish & 2 & 1,026 & 0,300 & 0,$438 ; 1,613$ & & \\
\hline
\end{tabular}


The studies with the learning stations technique were divided into two group, articles and Master's theses, in order to investigate whether this impacted effectiveness of learning stations. Calculations found that the average effect size values of the interventions done in articles and graduate studies were calculated as 0.804 and 0.928 respectively. According to the homogeneity test result, there is no significant difference between the effect size values calculated according to the type of the studies performed $\left(\mathrm{Q}_{B}=0.074 ; \mathrm{p}=0.786\right)$.

The effect of teaching practices on success in accordance with the learning stations technique was analysed within many disciplines such as science and technology, physics, general chemistry, life science, mathematics, social studies and Turkish. This analysis showed that the highest calculated effect size value was 1.224 for science and technology and the lowest was 0.013 for general chemistry. According to the homogeneity test result, there is a significant difference between the effect size values calculated by discipline.

\section{Discussion, Conclusion and Suggestions}

The aim of this study was to investigate the effectiveness of the learning stations technique used in studies carried out between 2000 and 2018 in Turkey. For this purpose, 13 empirical studies that met the inclusion criteria of the research from 29 experimental trials were included in the meta-analysis. A large proportion of the studies included in the research were articles using learning stations in science and technology courses at the primary education level.

Publication bias affects meta-analysis studies directly (Ustun \& Eryilmaz, 2014). In this regard, before the meta-analysis could be carried out, different methods were used to investigate whether publication bias was present. The results obtained with the Funnel Scatter Graph and Crop and Fill methods show that in case of publication bias related to the learning stations technique, inaccessible studies would not change the calculated effect size significantly. According to Rosenthal and Orwin's Fail Safe N method results, the studies that investigated the effectiveness of the learning stations technique were quite resistant to bias. The results obtained show that the studies used in this meta-analysis is not biased.

According to the results of the meta-analysis, learning stations-based teaching practices have a positive influence. According to Cohen's (1988) classification, the calculated average effect size is in the large effect size range. This result shows that learning stations-based teaching practices are significantly more effective than traditional teaching practices for classroom success. This result is consistent with meta-analysis studies comparing student-centered teaching practices with traditional teaching practices (Akdemir \& Karakuş, 2016; Capar \& Tarim, 2015; Gozuyeşil \& Dikici, 2014; Yesilpinar, Uyar \& Doganay, 2018; Yurt \& Polat, 2015).

In this study, it was investigated whether the effect sizes of using learning stations differs by education level. The largest calculated effect size was observed at the primary education level and the smallest effect size at the university level. There was a significant difference between the effect sizes of the studies according to level of education, according to the homogeneity test result. The application of the learning stations technique in the elementary, high school and university stages has large, medium and small effect sizes. These results show that the learning stations technique is more effective in increasing achievement at the primary education level than at the high school and university levels. The results obtained are consistent with the results of some meta-analysis studies examining the effect of student- 
centered teaching practices on course success (Akdemir \& Karakus, 2016; Capar \& Tarim, 2015).

The study also examined whether the effects of successful teaching practices based on the learning stations technique differs according to the duration of the application. Studies with 34 weeks of application had the highest effect size and those with 5 weeks of application and above had the lowest effect size. On the other hand, according to the homogeneity test result, there is no significant difference between the effect size values calculated according to the application period of the studies. There are studies in the field literature that examine the effect of student-centred teaching practices on achievement over the implementation period. In some of these studies, it has been found that the duration of application has a significant effect on average effect size (Yurt \& Polat, 2015) and in others it is not significant (Ayaz \& Soylemez, 2015; Dagyar \& Demirel, 2015).

It was also investigated whether the level of impact on the success of teaching practices based on the learning stations technique varied according to the type of study. Within this scope, the studies included in the research were divided into two groups: articles and Master's theses. The average effect size of Master's theses was large. As a result of the homogeneity test, there was found no significant difference between the effect size values calculated according to study type. In the literature, there are meta-analysis studies indicating that the effect of student-centered teaching practices on course success do not differ by study type (Ayaz \& Soylemez, 2015).

In this meta-analysis study, the effect of the learning stations-based teaching practices on academic achievement according to course type was also examined. The size of the effects of teaching practices in various disciplines including science and technology, physics, general chemistry, life science, mathematics, social studies and Turkish were examined. The highest effect sizes were observed in science and technology, social studies and Turkish lessons, while the lowest effect sizes were observed in general chemistry and mathematics. According to the homogeneity test result, there was found a significant difference between the effect size values calculated according to the course type. There are some meta-analysis studies that indicate that the effect of student-centered teaching practices on student achievement differs according to course type (Akdemir \& Karakuş, 2016) and others indicate that they do not differ (Ayaz \& Soylemez, 2015; Dagyar \& Demirel, 2015; Gozuyesil \& Dikici, 2014).

According to the results of the research, although there was not a statistically significant difference according to all the selected moderator variables, it was found to more effective to use the learning stations technique in primary education as the ideal education stage, 3-4 weeks as the ideal application period and in science and technology lessons as the ideal course for optimal student success.

One of the possible reasons that the learning stations technique may be more effective in science and technology is that the learning stations technique is more compatible with the nature of this course. Learning stations offer great opportunities for students to use the knowledge and skills they have learned in science and technology. In this way, students can develop concrete materials using the knowledge and skills they learn. This might have provided learners with pleasure, making their learning more effective. The fact that the learning stations technique is more effective at the primary education level might be due to the developmental characteristics of this age group, because this technique helps students to develop more intimate relations with their peers by creating a genuine gaming atmosphere. In 
this study, it was observed that the effect size values of the Master's theses were higher than the effect size values of the articles. In the thesis studies, research was carried out with larger samples and in a more controlled and meticulous manner. Depending on this situation, it can be said that more effective results have emerged in the thesis.

Based on the results obtained in the research, the following recommendations can be presented to practitioners, researchers and program development specialists:

- It has been found that the learning stations technique is very effective in increasing the success of students in different lessons compared to the traditional approach. In this respect, teachers should be encouraged to use the learning stations technique in appropriate subject areas.

- It has been found that station technology is more effective in increasing students' achievement in the science and technology courses. From this standpoint, the learning stations technique can be used especially in science courses.

- It has been found that the learning stations technique is more effective in increasing the learner success of the primary school students. In this respect, the use of station technology at the primary education level should be encouraged.

- The learning stations technique has been found to have an important effect in increasing the success of science and technology course in a positive direction. Accordingly, more emphasis should be placed on learning stations technique applications, especially in the science and technology curriculum.

- The average effect size value of the Master's theses was higher than the average effect size value of the articles. Possible reasons for this can be investigated.

- More studies can be done on the application of the learning stations technique in the courses such as physics, chemistry, and mathematics.

- It has been observed that the application of the learning stations technique is mostly carried out at the primary education level. More research is needed to investigate the effect of the learning stations technique on course success at different levels. For this reason, the learning stations technique can be applied and studied in different educational levels (primary, secondary, higher education) and different disciplines.

\section{References}

Studies marked with asterisk $\left(^{*}\right)$ were included in the meta-analysis

Akdemir, H. \& Karakuş, M. (2016). Yaratici drama yonteminin akademik basari uzerine etkisi: Bir meta-analiz calismasi [The effect of creative drama method on academic achievement: A meta-analysis study]. International Journal of Active Learning, 1(2), 5567.

Akgoz, S., Ercan, I. \& Kan, I. (2004). Meta-Analizi [Meta-analysis]. Journal of Uludag University Medical Faculty, 30(2), 107-112.

Albayrak, H. (2016). Astronomi konularında istasyon tekniginin ogrencilerin akademik basarisina ve astronomiye karsi tutumuna etkisi [The effect of the station technique to students' academic achievement in astronomy topics and students' attitudes to astronomy]. Unpublished master thesis. Erzincan University Institute of Science, Erzincan, Turkey. *

Arslan, A. (2017). Turkce ogretiminde istasyon teknigi kullaniminın ogrencilerde akademik basariya, tutuma ve kaliciliga etkisi [The effect of station technique on academic 
success, attitude, and retention in Turkish language teaching]. Unpublished master thesis. Cumhuriyet University Institute of Educational Sciences, Sivas, Turkey. *

Ayaz, M. F. \& Soylemez, M. (2015). Proje tabanli ogrenme yaklasiminin Turkiye'deki ogrencilerin fen derslerindeki akademik basarilarina etkisi: Bir meta-analiz calismasi [The effect of the project-based learning approach on the academic achievements of the students in science classes in Turkey: A meta-analysis study. Education and Science, 40(178), 255-283.

Benek, I. \& Kocakaya, S. (2012). Istasyonlarda ogrenme teknigine yonelik ogrenci gorusleri [Students' opinion on learning in stations technique]. Journal of Research in Education and Teaching, 1(3), 8-18.

Benek, I. (2012). Istasyonlarda ogrenme tekniginin ilkogretim 7. sinif ogrencilerinin fen ve teknoloji dersindeki basarilarina etkisi [Effect of the learning in stations technique on 7th grade secondary school students? achievement on science and technology course]. Unpublished master thesis. Yuzuncu Yil University Institute of Science, Van, Turkey. *

Borenstein, M., Hedges, L. V., Higgins, J. P. T., \& Rothstein, H. (2009). Introduction to metaanalysis. Hoboken, NJ: Wiley.

Cakmak, M. (2018). Istasyon tekniginin 6. sinif madde ve isi unitesindeki ogrenci basarisina etkisi ve ogrencilerin teknige iliskin gorusleri [The effect of station-based teaching method on the success of $6^{\text {th }}$ grade students in matter and heat unit and students' opinions on the method]. Unpublished master thesis. Dicle University Institute of Educational Sciences, Diyarbakır, Turkey.

Capar, G., \& Tarim, K. (2015). Efficacy of the cooperative learning method on mathematics achievement and attitude: A meta-analysis research. Educational Sciences: Theory and Practice, 15(2), 553-559.

Cohen, J. (1988). Statistical power analysis for the behavioral sciences ( $2^{\text {nd }}$ ed.). Hillsdale, NJ: Lawrence Earlbaum Associates.

Council of Europe (2015). Education for change, change for education. Teacher manifesto for the $21^{\text {st }}$ century of the conference. The Professional Image and Ethos of Teachers, April 2014, Council of Europe, Strasbourg.

Dagyar, M. \& Demirel, M. (2015). Probleme dayali ogrenmenin akademik basariya etkisi: Bir meta-analiz calismasi [Effects of problem-based learning on academic achievement: A meta-analysis study. Education and Science, 40(181), 139-174.

Demir, M. R. (2008). Istasyonlarda ogrenme modelinin hayat bilgisi dersindeki ust duzey beceri erisisine etkisi [The effect of learning station (center) model to the achievements of high level skills in life studies lessons]. Unpublished master thesis. Hacettepe University, Social Sciences Institute, Ankara, Turkey. *

Erdagi, S. (2014). Istasyon tekniginin fen ve teknoloji dersinin akademik basarisina etkisi [The influence of station technique on the academic success of Science and Technology lesson]. Unpublished master thesis, Kafkas University Institute of Science, Kars, Turkey. *

Erdogan, I. (2012). Egitimde degisim yonetimi [Change management in education]. Ankara: Pegem Academy Publishing.

Gozutok, F. D. (2007). Ogretim ilke ve yontemleri [Teaching principles and methods]. Ankara: Ekinoks Publishig.

Gozuyesil, E. \& Dikici, A. (2014). The effect of brain based learning on academic achievement: A meta-analytical study. Educational Sciences: Theory and Practice, 14(2), 642-648.

Guc, F., Korkmaz, O., Cakir, R., \& Bacanak, A. (2016). Istasyon tekniginin matematik dersi akademik basarisina etkisi ve ogrenci gorusleri [The effect of station technique on 
students' academic achievement in mathematics and students' views]. Mehmet Akif Ersoy University Journal of Education Faculty, 1(40), 171-190. *

Gunes, E. (2009). Fen ve teknoloji dersinde istasyon teknigi ile yapilan ogretimin erisiye ve kaliciliga etkisi [The effect of learning stations instruction on gain score and retention in science and technology lesson]. Unpublished master thesis. Hacettepe University Institute of Social Sciences, Ankara, Turkey. *

Gurbuz, T. (2011). Egitimde degisim: Bilgi yonetimi ve e-ogrenme [Change in education: Information management and e-learning]. XVI. Internet Conference in Turkey (30 November-2 December 2011), Ege University, Izmir, Turkey.

Hedges, L. V., Olkin, I. (1985). Statistical methods for meta-analysis. Orlando, FL: Academic Press.

Korsacılar, S. (2014). 9. sinif fizigin dogasi unitesindeki temel kavramlarin ogretiminde yasam temelli ogretim ve ogrenme istasyonlari yonteminin etkililigi [The effectiveness of real life context-based teaching and learning stations methods in teaching basic concepts in the 9th grade nature of physics unit]. Unpublished master thesis. Dokuz Eylul University Institute of Educational Sciences, Izmir, Turkey. *

Maden, S., \& Durukan, E. (2010). Istasyon tekniginin yaratici yazma becerisi kazandirmaya ve derse karsi tutuma etkisi [The effects of station technique on creative writing ability and its attitudinal effect on turkish lesson]. Journal of Turkology Research, 28, 299-312.*

Mergen, H. H. (2011). Ilkogretim 5.sinif sosyal bilgiler dersinde ogrenme istasyonlari uygulamasinin akademik basariya ve kaliciliga etkisi [The effects of learning stations technic on academic success and permanence in social sciences lesson in 5 th classes of primary school]. Unpublished master thesis. Afyon Kocatepe University Institute of Social Sciences, Afyonkarahisar, Turkey. *

Ocak, G. (2008). Yontem ve teknikler [Methods and techniques]. G. Ocak (Ed.). Ogretim ilke ve yontemleri [Teaching principles and methods]. Ankara: Pegem Akademi Publishing.

Ocak, G. (2010). The effect of learning stations on the level of academic success and retention of elementary school students. The New Educational Review, 21(2), 146-156. *

Ocak, G. (2015). Ogretim ilke ve yontemleri [Teaching principles and methods]. Ankara: Pegem Akademi Publishing.

Ozden, Y. (2005). Egitimde yeni degerler: Egitimde donusum [New values in education: Transformation in education] ( $6^{\text {th }}$ ed.). Ankara: Pegem Academy Publishing.

Pohtola, T. (2015). Differentiating instruction in EFL classrooms in secondary education. Inquiry project. Indiana University, Bloomington, Indiana.

Rothstein, H. R., Sutton, A. J., \& Borenstein, M. (Eds.). (2005). Publication bias in meta-analysis: Prevention, assessment and adjustments. West Sussex, England: John Wiley \& Sons.

Senemoglu, N. (2007). Gelisim, ogrenme ve ogretim [Development learning and teaching]. Ankara: Gonul Publishing.

Surucu, A., Ozdemir, H., \& Basturk, R. (2013). Fen bilgisi ogretmen adaylarinin kavram basarilarina istasyonlarda ogrenme modelinin etkisi [Effect of the learning in stations model to pre-service science teachers' concept achievements]. Electronic Journal of Social Sciences, 12(45), 52-62. *

Tomlinson, C. A. (1999). The differentiated classroom: Responding to the needs of all learners. Alexandria, VA: Association for Supervision and Curriculum Development Publications.

Tomlinson, C. A. (2001). How to differentiate instruction in mixed-ability classrooms. Alexandria, VA: Association for Supervision and Curriculum Development Publications.

Ustun, U. \& Eryilmaz, A. (2014). Etkili arastirma sentezleri yapabilmek icin bir arastirma yontemi: Meta-analiz [A research methodology to conduct effective research syntheses: Meta-analysis. Education and Science, 39(174), 1-32. 
Yesilpinar Uyar, M., \& Doganay, A. (2018). Ogrenci merkezli strateji, yontem ve tekniklerin akademik basariya etkisi: Bir meta-analiz calismasi [The effect of student-centered strategies, methods and techniques on academic achievement: A meta-analysis study]. Mersin University Journal of the Faculty of Education, 14(1), 186-209.

Yuksel, O. (2017). Evsel atiklar ve geri donsusm-kimya endustrisi konularinda istasyon tekniginin ogrencilerin akademik basarisina ve goruslerine etkisi [The effect of station technique on students' academic achievement and opinions in the teaching of household waste and recycling-chemical industry subjects]. Unpublished master thesis. Ordu University Institute of Science, Ordu, Turkey. *

Yurt, E., \& Polat, S. (2015). The effectiveness of multiple intelligence applications on academic achievement: A meta-analysis. Journal of Social Studies Education Research, 6(1), 84-122.

Dr. Mevlut AYDOGMUS, PhD,Assistant Professor for Curriculum and Instruction Department of Ahmet Kelesogllu Education Faculty of Necmettin Erbakan University in Konya, Turkey. Her field of research is pedagogical practice, curriculum development. He also works as vice coordinator for Erasmus Program in Ncemettin Erbakan University and carried out many educational projects.

Dr. Cihad Şentürk is an assistant professor at the Faculty of Education, Karamanoğlu Mehmetbey University, Karaman, Turkey. He also works as deputy dean in this faculty. His research interests include curriculum and instruction, curriculum development, teachinglearning process, primary education crriculum and mixed method research. 